\title{
Why should I listen to my conscience? Equity and the question of ontological obligation
}

\section{Introduction}

What is it about obligation that obligates us? Is it possible to answer this question whilst remaining within the sphere of obligation as obligation; that is, without resorting to external justifications of why it is better to obey obligations than not to? It is at the very least arguable that, for the most part, obligation is only a secondary and derivative concern for modern law. Obligations are often constructed negatively by means of proscription (I am obligated not to act dangerously). Or else, they derive from the atomistic entitlement inherent in modern legal subjectivity (I am obligated to honour my freely-made agreements). Or sometimes by a combination of both (I am obligated to respect others' property rights, for example).

This chapter takes up the challenge of thinking obligation as distinct and independent of the liberal, modern articulation of individual capacity and entitlement: as 'primary obligation' and not simply the opposite side of another person's rights. The implications of this need to be sketched out. To truly isolate and purify a notion of obligation, to separate it from the egotic, formal reciprocity implicit in rights, would be to trace what Roberto Esposito understood to be the very essence of community itself, the munus denoting the obligatory social bond of "debt" to others that is distinctly anterior to the protective rights-based apparatus of modernity. ${ }^{1}$ This would be an obligation logically prior to positive law as we know it and prior to the modern subject. ${ }^{2}$ Such a conception therefore cannot help but foreground the necessary connection between obligation and the political.

This inquiry also presents an opportunity to consider the under-theorised linkage of private law and the social bond. To find a way into this, the chapter considers the field of English equity as a possible, albeit mediated, expression of primary obligation. ${ }^{3}$ In particular, by invoking an elementary language of 'conscience', equity — in a manner unlike any other area of English law-presents a grounded route into thinking about why and how we have duties to others. In short, one is obligated in equity by conscience itself, as a faculty for understanding one's situated responsibility towards others. Moreover, by referring juridical obligation back to the self-evident ethical disposition of conscience, an orientation that instantiates itself in equity without an apparent need to be justified by anything other than itself, we are provoked to ask whether such duty demands ontological significance. In other words, if it is not itself derivative of some other legal or moral concept, nor represents a technical principle defined by a particular end, does conscience say something about our very being, placed within the ethical commitment

\footnotetext{
${ }^{1}$ Roberto Esposito, Communitas: The Origin and Destination of Community (Stanford: Stanford University Press, 2010), in particular pp. 3-6.

${ }^{2}$ On this form of critique of modernity, see Esposito Bios: Biopolitics and Philosophy (London: University of Minnesota, 2008) and Immunitas: The Protection and Negation of Life (Cambridge: Polity Press, 2008).

${ }^{3}$ For an expanded argument, see Matthew Stone, 'Equity, Property, and the Ethical Subject' (2017) 11(1) Pólemos: Journal of Law, Literature and Culture 73-95.
} 
of community? If this suggestion seems grandiose, note how easily it aligns with the enduring rhetorical idea of listening to one's inner voice, being true to one's ethical self, and so on. ${ }^{4}$ With this in mind, this chapter will consider theoretical approaches, notably within Heideggerian and post-Heidegerrian thinking, which see conscience as an important expression of our relationship with our Being and the responsibilities we therefore assume therein. If this connection proves persuasive, it becomes possible to understand the juridical deference to conscience as invoking the normative weight of precisely this sort of foundational, primary obligation. The ultimate question that this chapter will confront, therefore, is whether ontology itself really can deliver obligations, both in the sense of whether we have an obligation to listen to our conscience, and whether the substance spoken by conscience can be grasped with some level of objectivity. This is not, therefore, simply to ask of the manner that concrete obligations may be understood ontologically, but also to ask of obligation that is delivered by our relationship with Being as such. By linking this theoretical enquiry of this chapter with a field of positive law, we may see not only the manner in which primary obligation might find a form of juridical expression, but also the unavoidable contortions and difficulties in this passage from the fundament to the surface level of tangible rules and principles.

It could be asked why, other than scholastic intrigue, this line of inquiry is important. A hasty response would be to say that it outlines the way a field such as equity gives expression to resistance against the legal construction of intersubjectivity in liberal modernity. If such a foundational ethical affectivity finds a form of articulation in equity, then it may provide an avenue of critique against the excesses of a hegemonic rights-based jurisprudence. One has to be a bit careful here, however. Equitable jurisprudence, in the familiar institutional form that began to coalesce around the $16^{\text {th }}$ and $17^{\text {th }}$ centuries, is itself very much a product of the burgeoning modernity of the time. Equity itself cannot be romanticised as an untainted expression of a utopian social bond, and to a large extent now insinuates itself into the virulent logic of contemporary capital. ${ }^{5}$ Nevertheless, if the rhetorical appeal to conscience can be tied to some form of vital ethical sensibility, even if as the contorted and assimilated trace, then a certain priority may be restored to its concept. A priority that elides the tired trope that equity is simply an auxiliary appendage of modern law.

\section{Equitable obligation}

Equity is at essence a mature jurisprudence of obligation in which a persistent appeal to conscience has in various ways worked to resist the sanctity of formal rights and individual entitlement in the fields of property and contract. Yet at the same time it is a repressed jurisdiction, largely absent from traditional

\footnotetext{
${ }^{4}$ On the idea of conscience as a voice of the inner self, see: Larry May, 'On Conscience' (1983) 20(1) American Philosophical Quarterly 57-67; Iredell Jenkins, 'The Significance of Conscience' (1955) 65(4) Ethics 261-270.

${ }^{5}$ Similarly, it is arguable that the modern juridical form of conscience represents a sublation of divine authority into the sovereignty of the state.
} 
private law theory and doctrinal jurisprudence, and commonly constructed as the exceptional supplement to the infrastructure of modern law. Of importance, here, is not so much the substance of equitable duty but the manner in which it is formulated. The centrality of conscience to the construction of obligations, particularly by4 reference to the defendant's own conscience being bound or affected, is a matter not only of historical significance ${ }^{6}$ but also still vital in seminal statements of contemporary equitable reasoning. ${ }^{7} \mathrm{~A}$ paradigmatic example occurs where a person has acquired title to an asset without any formal impropriety, yet they are capable of reflecting on contextual facts which would make it unconscionable to keep the property for themselves. In such a scenario where one's conscience has been affected, equity may charge the person with property obligations owed to others, displacing the conventional association between possession and rights. ${ }^{8}$

In a sense, of course, the deference to conscience is a rhetorical fudge. It allows equity, as a legal institution, to displace its justification of liability on the basis that it is already evident in a sphere of ethical intuition, outside the technical cut and thrust of conventional doctrine. This displacement is more than merely symbolic: as a tribunal of conscience, medieval equity had more in common with religious process than the application of legal reasoning as we would recognise today. ${ }^{9}$ Chancellors were concerned with the salvation of defendants' souls, ${ }^{10}$ and unlike the English common law, Chancery adopted an inquisitorial rather than purely adversarial procedure. As J.H. Baker describes, the chief methods of gathering evidence consisted of interrogation and deposition, owed to the influence of Canon law and the denunciato evangelica. ${ }^{11}$ There is little doubt that this process was predicated on the guilty introspection of the sinful party. As Dennis Klinck surmises, "[medieval] Chancery proceeded secundum conscientam, inquiring at large into the facts and particularly probing the consciences (bound by oaths) of the parties to make them come to terms with what they inwardly know to be the truth."12 This reflects an essential characteristic, whereby conscience is somehow intimately personal yet still determined within the

\footnotetext{
${ }^{6}$ E.g. the famous words of the Lord Chancellor Thomas Egerton in The Earl of Oxford's Case (1615) 1 Ch Rep 485 : "The Office of the Chancellor is to correct Men's consciences" (p. 486).

${ }^{7}$ One of the notable aspects of the place of 'conscience' in equitable reasoning is the casual context in which it is deployed, signifying its self-evident quality without providing a comprehensive definition. Its function as a porous and diffractive signifier will prove important for later parts of this chapter's argument. Nevertheless, key examples of modern cases decided with reference to the party's conscience are as follows: On the constitution of express trusts: Choithram v Pagarani [2001] WLR 1; on constructive trusts in commerce: Westdeutsche Landesbank Girozentrale v Islington London Borough Council [1996] 2 WLR 802; on constructive trusts of the family home: Grant v Edwards [1986] Ch 638; on fiduciary obligations: Boardman v Phipps [1967] 2 AC 46; on receipt of trust property in breach of trust: BCCI v Akindele [2001] Ch 437; on proprietary estoppel: Gillett v Holt [2001] Ch 210; on undue influence: Credit Lyonnais Bank Nederland v Burch [1997] CLC 95.

${ }^{8}$ Most notably, the obligations of trusteeship.

${ }_{9}^{9}$ Dennis Klinck, Conscience, Equity and the Court of Chancery in Early Modern England (Farnham: Ashgate, 2010), pp. 2328.

${ }^{10}$ Klinck, Conscience, p. 23, referring to Franz Metzger, 'The last Phase of the Medieval Chancery' in Alan Harding (ed.), Law-Making and Law-Makers in British History (London: Royal Historical Society, 1980).

${ }^{11}$ J.H. Baker, An Introduction of English Legal History, 4th ed. (Oxford: Oxford University Press, 2007), p. 103. The latter doctrine holds that the church possesses its own authority to take action in the cleansing of the soul of a sinner. See also: Helmut Coing, 'English Equity and the Denunciato Evangelica of the Canon Law' (1955) 71 Law Quarterly Review 223-241; Amalia D. Kessler, 'Our Inquisitorial Tradition: Equity Procedure, Due Process, and the Search for an Alternative to the Adversarial' (2005) 90(5) Cornell Law Review 1181-1275, section II.

12 Klinck, Conscience, p. 29.
} 
structure of a legally-cognisable imperative. As Alasdair Hudson has emphasised recently, this pairing of a subjective mode of individual interpretation and an objectively discoverable set of normative ideas permeates equity's model of conscience to this day. ${ }^{13}$

Upon the advent of modernity, in which equitable justice eventually became translated into the structure of recognisably 'legal' form, this jurisdiction of privileged knowledge was retained. Conscience, and its corollary of unconscionability, continued to invoke a self-evident authority whilst resisting any unifying reduction to static rules. ${ }^{14}$ And one can still recognise the same contemplative dimension of the confessional relationship after this time. For instance, in his 1760 text, Principles of Equity, one of the very few jurisprudential meditations on the subject, the jurist and philosopher Lord Kames talks of the way equity must achieve justice not only for those affected by one's actions, but also with respect to the duty the defendants owe themselves. ${ }^{15}$ Not only does this illuminate the manner in which equitable conscience describes a relationship with oneself, it also reveals how it requires a reflective element. ${ }^{16}$ It is not that humanity simply has an intrinsic inclination towards shared, substantive moral values; rather, conscience only becomes comprehensible when the subject is capable of apprehending its own existing ethical orientation, as one's "innate sense or conviction of a common nature."17

Conscience therefore foregrounds a crucial question of voice. To be obligated an obligation must be heard, if not voiced by some external command then by a movement of thinking. Indeed, it is precisely the distinction from a vertical legal command that informs its distinct normative weight. Kant's categorical imperative, arguably the exemplary model of conscientious obligation in modern Western philosophy, ${ }^{18}$ demonstrates this well. Conscience directs us inwards, impelling us to listen to ourselves as opposed to deferring unreflectively to established principles. For Kant, the voice of conscience is the voice of reason, not as the simple application of moral judgment to human actions, but as reason judging itself. ${ }^{19}$ Conscience is therefore a vigilance of thinking in which judgment is subjected to judgment. It is a voice that passes through the thinking subject whilst simultaneously transcending it, and which is incorporated into the very "being" of humankind. ${ }^{20}$ Of course, the juridical appropriation of conscience which occurs in the courts of Chancery redoubles this question. Conscience cannot merely be the

\footnotetext{
13 Alastair Hudson, 'Conscience as the Organising Concept of Equity' (2016) (2)1 Canadian Journal of Comparative and Contemporary Law 261-299, at p. 264.

${ }^{14}$ Note Hudson's claim that this lack of definition does not prevent the development of conscience as an objective form of moral reasoning, ibid.

${ }^{15}$ Henry Home, Lord Kames, Principles of Equity, $3^{\text {rd }}$ ed. (Indianapolis: Liberty Fund, 2014), p. xli.

${ }^{16}$ Consider a modern example in the law of trusts: "Unless and until the trustee is aware of the factors which give rise to the supposed trust, there is nothing which can affect his conscience", per Lord Browne-Wilkinson, Westdeutsche v Islington, op cit, p. 709.

${ }^{17}$ Kames, Principles of Equity, p. xliv.

18 "The categorical imperative, which as such only affirms what obligation is, is: Act upon a maxim that can also hold as a universal law" (Immanuel Kant, The Metaphysics of Morals (Cambridge: CUP, 1991), p. 51). On the categorical imperative as conscience, see J. David Velleman, 'The Voice of Conscience' (1999) 99 Proceedings of the Aristotlian Society 57-76.

${ }^{19}$ Immanuel Kant, Religion within the Bounds of Bare Reason (Cambridge: Cambridge University Press, 1998), p. 179.

${ }^{20}$ Kant, Metaphysics of Morals, p. 233.
} 
sovereign voice of positive law, but it also cannot merely be the free preferences of the subject. Ethics and authority become entwined in mutual contradiction. ${ }^{21}$

The next steps involve thinking further about whether, and how, the normativity of conscience can be supported philosophically as a primary obligation whilst still operating meaningfully in law. But before proceeding, it may be useful to crystallise various key positions introduced so far. Firstly, conscience obligates via a structure of non-coincidence of self. As the frequent judicial references to being bound by one's own conscience demonstrate, ${ }^{22}$ its symbolic work requires it to be available to the subject whilst simultaneously differentiated. It addresses the self, as a faculty of the self, yet is also received or 'heard' as somehow something other, and which can be interpreted by the court. Secondly, as an ethical faculty, conscience addresses people's connectedness, and puts the fate of the other directly in the self's field of concern. Equitable conscience is framed as the responsibility that flows from one's ability to reflect on the nature and impact of circumstances and actions. This is of course the condition of conscience producing a distinct obligation that is not merely derivative of aggregated individual entitlements. Thirdly, at its most elementary, conscience presents a formal structure of ethical sensibility rather than a mere set of moral values. Conscience cannot be reduced down to a charter of ascertained rights and wrongs, but instead represents the availability of thinking about rightness and wrongness. As such, equity offers no comprehensive definition of 'good conscience', instead insinuating its intuitive availability, and instantiating it within case law.

\section{Obligation and ontology}

Whilst one can easily accept that conscience has a vital and dynamic influence in the language of equity, we have yet to reveal any direct justification as to exactly why we should obey it, in other words, its precise normative status. This question is of particular significance for equity, as the deference to conscience relies precisely on eliding the common law dependence on the sovereign's own imperative authority. As an expression of inner self but also somehow always non-coincidental with self, the structure of conscience also presents norms that cannot derive from publicly deliberated principles, ${ }^{23}$ nor from the subject's immediate personal preferences. Conscience teaches the equitable subject; but still, why should we listen?

\footnotetext{
${ }^{21}$ See Matthew Stone, 'The Contradictions of Conscience', forthcoming.

22 Supra note 7.

${ }^{23}$ Contrast with Hudson, 'Conscience as the Organising Concept of Equity'. The weakness in Hudson's argument is that he does not explain why, if conscience reflects objective moral expectations, it is expressed in such obfuscatory language. Hudson's argument leads to the necessary conclusion that conscience in equity is no different from, say, dishonesty in criminal law, or the duty of care in tort. And if that is the case, why are courts unable to define it with an equivalent level of precision?
} 
One immediate answer would be that conscience taps into an ethical authenticity invested in a sense of inner self. Efforts to consolidate existing philosophies of conscience emphasise how it is felt as a deeper truth of the self, such that there is an unpalatable type of existential discord in veering into inauthentic behaviours. ${ }^{24}$ The obligation here is experienced as being produced by the real 'me' that always rests more firmly in the soul than the surface 'me' capable of distraction by corrupt and unreflective impulses. To take this approach, equity would serve to teach the subject about itself, combining ethical knowledge with institutional authority. To support this outlook, consider the jurist Christopher St German's seminal theory of early modern equity, contained in the 1518 treatise Doctor and Student. Here, conscience is posed as a form of grounded reasoning by which the subject seeks to interpret and apply synderesis, a source of divine ethical truth that inheres in people as the "motive force of the rational soul". 25 What obligates, in this sense, is one's own personal inner connection to this underlying ethical essence. All people are capable of apprehending synderesis, albeit imperfectly, and so the courts of equity are legitimated in holding individuals to account where they failed to heed its message through the work of conscience.

The idea that such a mode of normativity displays a distinctly ontological structure is has already been observed frequently in existing literature. ${ }^{26}$ Indeed, it seems a small step to frame synderesis as representing an aspect of our underlying Being, which the conscientious subject seeks to illuminate and act upon. Understood this way, conscience is less a conventional command than it is an orientation towards an inner essence, ${ }^{27}$ and equity would appear to speak with the weight of ontology itself. However, such an apparent connection between obligation, ontology, and authority cannot be made too quickly, especially if we want to divest it of lingering theological overtones. Here, Heidegger's work assists in unravelling this difficult question about how normativity relates to authenticity, giving us a reason why it is better to listen to conscience than not. For Heidegger, conscience is an important part of 'Dasein', the being that is concerned with its own Being. Conscience calls Dasein away from the triviality of everyday life and towards an authentic connection with its potentiality. ${ }^{28}$ The inauthentic mode of life describes the way Dasein may find itself distracted in the general and amorphous structures of "manipulable rules and public norms", ${ }^{29}$ without reflecting properly on the potentiality it has within its own situated Being.

\footnotetext{
${ }^{24}$ For example, see Iredell Jenkins' analysis of our compulsion towards “moral or psychic equilibrium”: Jenkins, 'The Significance of Conscience, p. 262.

${ }^{25}$ Christopher St German, St German's Doctor and Student, ed. T.F.T. Plucknett and J.L. Barton (London: Selden Society, 1974), p. 81.

${ }^{26}$ See, e.g., Amanda Russell Beattie, Justice and Morality: Human Suffering, Natural Law and International Politics (Farnham: Ashgate, 2010), p. 89; Robert J. Smith, Conscience and Catholicism: The Nature and Function of Conscience in Contemporary Roman Catholic Moral Theory (Oxford: University Press of America, 1998), p. 10; J Ratzinger, 'Conscience and Truth' (2010) 37 Communio 529-538, at 535;

27 This is reflected quite pointedly by Lord Kames, op cit. Also, Walter Ashburner: “...the court, out of tenderness for his conscience, will deprive him, notwithstanding his resistance, of what is so heavy a burden upon it" (Ashburner's Principles of Equity, $2^{\text {nd }}$ ed. (London: Butterworth \& Co, 1933), p. 39).

${ }^{28}$ In particular, see his analysis of what he calls Das Man ['The They', or 'The One']: Martin Heidegger, Being and Time (Oxford: Blackwell, 1962), pp. 315-316.

${ }^{29}$ Ibid., p. 334.
} 
Conscience therefore draws us to a more meaningful understanding of ourselves. In this manner, Heidegger addresses the problem of how conscience can be both a general phenomenon, in that all instances of Dasein are capable of hearing its call, yet is rooted in the specificity of the one who questions and the answers they receive.

It is important to understand that Heidegger is not posing conscience as a conduit of determinate moral values. Such conscience does not tell us what is right and what is wrong. Instead, it describes a mode of enquiry that is necessary to properly understand rightness and wrongness as such. At its most fundamental, it addresses not a guilt for a specific wrong but a primordial guilt inherent in all of us, logically prior to any solidified conception of good and bad. ${ }^{30}$ We are constitutively guilty precisely because, as Dasein, we are capable of confronting the relationship between our actions and our potentiality. The introspective experience of conscience is therefore, before any question of specific deeds, a taking responsibility for one's Being. Immediately, we can see certain core themes that mirror the ethereal character of conscience within the juridical matrix of equity. Both contexts invoke an orientation towards underlying self-knowledge which is not immediately present at the surface level of articulation. As considered above, equitable conscience cannot be reduced to a schema of tangible substantive rules, instead appealing to a sense of essential truth about ourselves and our situated responsibility towards others. Indeed, a core characteristic of equitable conscience lies precisely in the way it cannot be crystallised comprehensively in this manner, and therefore cannot as easily be contorted or circumvented by technical doctrinal argument (consider, for example, the way that a disingenuous obedience with the formalities of statute becomes irrelevant if the party has been deemed to have acted unconscionably ${ }^{31}$ ).

Of course, the parallels between the equitable and Heideggerian models should not be overstated. It is important to acknowledge, for instance, that whilst underdetermined as a concept, particular instantiations of conscience in equity inevitably manifest and solidify in case law. The inner voice of conscience means little in a juridical sense without being supplemented by the public voice of legal institutions. And meanwhile, whilst the idea of a more authentic relationship with one's being may provide us with reasons for us to listen to our conscience, Heidegger stops short of framing it as an obligation in any recognisably legal or political sense. ${ }^{32} \mathrm{He}$ therefore forces us to confront a distinction between conscience as structure of ontological concern, and as a concrete commitment of political community. Heidegger does not present any necessary deduction from one sphere to the other. ${ }^{33}$

Such a separation of the personal and political inevitably invites critical perspectives to be taken on Heidegger's ontology and its ability to make sense of norms. Mikas Ojakangas goes as far as to say that

\footnotetext{
${ }^{30}$ Ibid., p. 332.

31 E.g. Rochefoucauld v Boustead [1897] 1 Ch 196.

32 On the difficulty of framing authenticity as a conventional obligation, see Steven Crowell, Normativity and

Phenomenology in Husserl and Heidegger (Cambridge: Cambridge University Press, 2013), pp. 300-303.

33 Indeed, his notion of guilt must be "detached from relationship to any law or 'ought' such that by failing to comply with it one loads himself with guilt.” Ibid., p. 328.
} 
it "relentless individualizes Dasein down to itself," not in the sense of producing an egotic autarkic subjectivity, but nevertheless in the sense of distinctly singular responsibility. ${ }^{34}$ The implications of this are put bluntly by Lambert Zuidevart: "[i]n Kantian terms, to make individual Dasein the source of its only genuine norms is to reduce moral obligations to one's pursuing idiosyncratic maxims without asking whether those maxims are right.” 35 One must also ask of the potentially ideological character-arguably both conservative and essentially humanist ${ }^{36}$ — to such a prioritisation of something akin to Dasein, which may draw primary obligation away from a robust sense of a social bond. Efforts on the contrary to delineate a more prominent ethical responsiveness of the Heideggerian conscience must rely upon an emphasis of the ontological importance of the with. ${ }^{37}$ In order to persevere with this line of enquiry, we therefore need to shift the frame of reference back to a more vigorous conception of community.

\section{Sharing obligation: a categorical imperative}

A crucial challenge for any idea of conscience as primary obligation is to articulate some form of social affectivity. If we accept, as suggested in the previous section, that the symbolic deployment of 'conscience' in law invokes some sort of ontological weight we also need to understand more clearly how this imperative addresses our responsibility to others. If this should be the case, conscientious introspection must be, more profoundly, a delivery to deeper communal challenge of ontology. At this point it is helpful to turn to the work of Jean-Luc Nancy as a way to bring out a more pronounced sense of community. Nancy's philosophical writing resembles in many respects a critical development of Heidegger's approach, principally through the outright prioritisation of Being-with above any conventional conception of subjectivity ${ }^{38}$ or post-subjectivity such as Dasein. Being-with is therefore the basis of community; or put otherwise, community, as the 'with', is the very expression of Being. ${ }^{39}$ For Nancy, Heidegger failed to take the concept of Being-with far enough, instead allowing it to inform a

\footnotetext{
${ }^{34}$ Mika Ojakangas, The Voice of Conscience: A Political Genealogy of Western Ethical Experience (London: Bloomsbury, 2013), p 18.

${ }^{35}$ Lambert Zuidervart, 'Truth and Authentication: Heidegger and Adorno in Reverse', in Iain MacDonald and Krzysztof Ziarek (eds.), Adorno and Heidegger: Philosophical Questions (Stanford: Stanford University Press, 2008$)$, p. 32. ${ }^{36}$ Consider the critique of the intrinsic vulnerability of Heidegger's philosophy to the political instrumentalisation of the human. E.g., Tom Rockmore, On Heidegger's Nazism and Philosophy (Oxford: University of California Press, 1991); contrast with Julian Young, Heidegger, Philosophy, Nazism (Cambridge: Cambridge University Press, 2008).

${ }^{37}$ Heidegger himself claimed that being-with, or Mitsein, is a component of Dasein: Being and Time, Part One, chapter IV. See Peg Birmingham, 'Ever Respectfully Mine: Heidegger on Agency and Responsibility', in Arleen B. Dallery et al (eds.), Ethics and Danger: Essays on Heidegger and Continental Thought (Albany: SUNY Press, 1992), pp. 109-123.

Consider also the argument that Heidegger's insight is not to provide any normative theory of law, but to allow us to understand what it means to think about law: Oren-Ben Dor, Thing About Law in Silence With Heidegger (Oxford: Hart, 2007).

38 'In a certain way, there has never been, and never will be, a philosophy 'of the subject' in the sense of the final closure in itself of a for-itself.", Jean-Luc Nancy, Being Singular Plural (Stanford: Stanford University Press, 2000), p. 29. See also, Jean-Luc Nancy, "Introduction" in Eduardo Cadava et al (eds.), Who Comes After the Subject? (London: Routledge, 1991), pp.1-8.

${ }^{39}$ Jean-Luc Nancy, The Inoperative Community (Oxford: University of Minnesota Press, 1991), p. 58.
} 
harmful distinction between proper and improper social formations..$^{40}$ Nancy therefore takes up the challenge of thinking the 'with' not as a mere attribute of Dasein, but as the condition of possibility for Being itself. But more specifically, it is crucial to note the work he produced in the late 70 s and early $80 \mathrm{~s}$ on the notion of Being's obligating character ("being-obliged"41), and specifically in relation to his reading of the Kantian source of conscience within the domain of reason, namely the categorical imperative.

Yet it must first be noted that by Kant's time, the connection of obligation and rationality was already familiar to scholars of equity. As we have already noted briefly, confounding the view of equity as discretionary justice, the work of St German in particular had posed its obligations as rooted in the coextensive authority of both reason and God. It may be of little surprise that the correspondence between synderesis, a central part of St German's theory, and Kant's categorical imperative has not gone unremarked upon. ${ }^{42}$ In the former, conscience itself is a mode of interpreting synderesis, an innate ethical orientation. What needs to be emphasised now is the aspect of synderesis that led St German to describe it as nothing less than "the law of reason" itself. ${ }^{43}$ It is by appealing to the transcendental availability of conscience that it can deliver an obligation that is both recognised by and expressed within legal reasoning, whilst originating in a deeper unconditional truth about ourselves that cannot be fully presented to the graspable domain of rules and principles. Furthermore, St German argued that because our power to make positive law is granted by God, "conscience must be ordered by the law". ${ }^{44}$ In other words, recalling his correspondence of reason and the divine, equity distinguishes itself by invoking a responsibility that runs through us all and implicates us personally in the social commitment of law. Conscience distributes a shared bond of reason that bears inextricably upon the authorship of law, and which manifests in the exceptional jurisdiction of Chancery. What both Kant and St German share in their ideas of conscience is the posing of a common responsibility for the very necessity and rationality of obligation, manifesting as an irrevocable commitment to law itself.

In his essay 'The Kategorein of Excess', Nancy similarly emphasises the connection between the categorical imperative and the movement of thinking, and draws out a further connection with freedom. Obligation is not something that can be reduced to an external demand (otherwise it is rooted in nothing more than sovereign violence), but nor is it an invention of the atomised self. At its heart, this obligation does not tell us what we should do; rather it obligates us with respect to obligation itself, by demanding that we legislate and create obligations. This is, therefore, a "law of making the law", or put alternatively, a law "of law making". ${ }^{45}$ Why must we make the law? It is, as Nancy describes, a factum rationis—“it imposes

\footnotetext{
40 Jean-Luc Nancy, 'The Being-With of Being-There', (2008) 41(1) Continental Philosophy Review 1-15.

${ }^{41}$ Jean-Luc Nancy, Jean-Luc Nancy, 'The Free Voice of Man', in Jean-Luc Nancy and Philippe Lacoue-Labarthe, Retreating the Political (London: Routledge, 1997), pp. 32-51, at p. 51; Jean-Luc Nancy, A Finite Thinking (Stanford: Stanford University Press, 2003), p. 134.

42 See: Ojakangas, p. 149; Anders Schinkel, Conscience and Conscientious Objections (Amsterdam: Pallas Publications, 2007). pp. 265-7; Frank K. Flinn, Encyclopedia of Catholicism (New York: Infobase 2007), p.179

43 St German, Doctor and Student, chapter 13.

${ }^{44}$ Mark Fortier, The Culture of Equity in Early Modern England (Aldershot: Ashgate, 2005), p. 62.

${ }^{45}$ Nancy, A Finite Thinking, p. 140, original emphasis.
} 
itself as a fact imposes itself". ${ }^{46}$ In other words, it is simply not possible to take up freedom and to think without receiving the imperative, therefore without assuming responsibility for what thought produces. The rationality of the imperative means that freedom cuts across the subject, not as a possession or abstract entitlement, but as the enjoinment of the subject towards its beyond in the movement of thought. In this sense, Nancy can claim that respect for the law is 'subjectivity' itself, in which we are orientated towards a law—orientated towards the fact of reason in law. ${ }^{47}$

Nancy innovates Kant by exploring the ontological aspect of this bond, developing what Francis Raffoul has aptly termed a 'categorical imperative of being'. ${ }^{48}$ The key to understanding this is found in his position on the ineluctable character of abandonment: we are abandoned to finitude, to Being without ground, without transcendence, and — contra Heidegger—without essence. Abandonment therefore entails that the categorical imperative to make good law (our obligation to obligate) does not arrive from somewhere, but is simply co-extensive with Being itself. The categorical imperative is nothing less than "an absolute call, and order or command, to be". ${ }^{49}$ As such, Nancy does not present us with an imperative to withdraw into the quiet domain of solicitude with respect to Being. It is an irrecusable and social responsibility for the distribution and sharing of Being. James Gilbert-Walsh describes this complicated structure by claiming that the imperative is voiced as "interruption". ${ }^{0}$ This term is useful in conveying the way that Being cannot be left to settle upon essential foundation, entailing the perpetual maintenance of the question of the sense and meaning that Being delivers. The imperative rests upon the obligatory character of the diffusion of Being through interruption itself. Interruption is structured in a paradoxical bind between its own withdrawal, its unavailability to presence, and its necessary presentation in always-inadequate instances of figuration. ${ }^{51}$ In this sense we may understand more precisely how obligation is doubled back on itself. One is obligated to be-obligated. Or as Gilbert-Walsh puts it rather more carefully:

'We' do not 'have' a sense of responsibility; we are our (broken) sense of responsibility. Or, rather, the sense of responsibility which we have always relates back to and is interrupted by the sense of responsibility which we are. ${ }^{52}$

By presenting us with a categorical imperative of Being, can we still speak within the idiom of conscience, which impels us to consider the intractable position of our own thoughts and actions with a sphere of communal reason? Or, more drastically, by tying the Kantian injunction of reason to the barest facticity

\footnotetext{
46 Ibid., p. 143.

47 Ibid., p. 147.

${ }^{48}$ François Raffoul, 'Abandonment and the Categorical Imperative of Being', in Benjamin Hutchens, Jean-Luc Nancy: Justice, Legality and World (London: Continuum, 2012), pp. 65-81.

49 Ibid., p. 75.

50 James Gilbert-Walsh, 'Broken Imperatives: The Ethical Dimension of Nancy's Thought' (2000) 26(2) Philosophy and Social Criticism 29-50.

${ }^{51}$ Nancy here invokes the structure of Derrida's différance, that interruption is never present to itself. The relation of Nancy's ontology to differrance will be considered later in the article.

${ }^{52}$ Gilbert-Walsh, 'Broken Imperatives', p. 44.
} 
of existence do we dissolve the intelligible status of obligation? This form of ontological duty is necessarily an obligation of an order removed. It is an obligation to be obligated by Being, a fundamental responsibility laid down by our existence and freedom. Such an outlook does not regard Being as producing obligations in the sense of informing us how to act; it is only capable of aligning itself with the fundamental necessity of obligation as such; the claim that obligation is obligatory. Whilst Nancy claims that Being is taken up as a 'command', 53 he poses the 'receiving' of a command that comes from nowhere. This is of course precisely the implication of his thesis on abandonment- there is no essence, much less any form of transcendent commander, from which the obligation is issued. This reading of the categorical imperative still evokes the voice of Kantian conscience: " $[$ t]he imperative is the proximity to self where reason hears itself." ${ }^{54}$ Yet the effect is the erasure of the gap between subject and command that one intuitively expects, leading to conclusions that are at risk of tautology or circularity. ${ }^{55}$ As Raffoul finds in his analysis, the obligation of Being may be reduced to saying that "being must come forth" ${ }^{56}$ Or in the words of Meurs and Devish, the imperative is simply that "being urges us to be", without deference to anything other than the fact of Being itself. ${ }^{57}$

Such an outlook therefore appears to present an obstacle separating primary obligation and the normative aspect of positive law. As our exploration of equity makes clear, conscience in law must be judicially interpretable and capable of delivering some sort of injunction about our responsibilities to others. If the fundamental obligation is found to be as encompassing as Being itself, how can we make sense of the difficult decisions demanded by ethics and justice? To see how far this problem can be addressed, and to eventually to tie the analysis back to equity, consider Nancy's revisitation of the imperative in the question of writing. The point of connection here is found in his claim that abandonment to finitude is precisely equivalent to the notion of différance, as coined by Derrida. Différance describes the irresolvable condition of all writing, that it relies upon a differential and endless chain of signifiers with the effect of a perpetual deferral of meaning. ${ }^{58}$ Both finitude and differance therefore describe the same deferral of presence: finitude is what is left in the absence of ground ("the infinity of the deferring of presence ipso facto constitutes... finitude" $\left.{ }^{59}\right)$. Nancy takes up Derrida's position that there is an imperative given in difference. ${ }^{60}$ Having already claimed that obligation emerges unconditionally in abandonment to finitude, Nancy can therefore draw the conclusion that

\footnotetext{
${ }^{53}$ Raffoul, 'Abandonment', p. 75.

${ }^{54}$ Nancy, 'Free Voice of Man', p. 47.

55 "The command 'Act' does not convert itself into 'You are having-to-act' [Tu es devant-agir]", Ibid.

56 Raffoul, 'Abandonment', p. 79.

${ }^{57}$ Pieter Meurs and Ignaas Devisch, 'The Meaning of Sense', in Tara Mulqueen and Daniel Matthews (eds.), Being Social: Ontology, Law, Politics (Oxford: Counterpress, 2015), pp. 47-57, at p. 56.

58 See Jacques Derrida, 'Différance', in Margins of Philosophy (Brighton: Harvester Press, 1982), pp. 1-28.

${ }^{59}$ Nancy, 'Free Voice of Man', p. 46.

${ }^{60}$ Ibid. A similar, and extended, argument can be found in Simon Critchley's claim that there is an ethics in deconstruction: Simon Critchley, The Ethics of Deconstruction: Derrida and Levinas, $3^{\text {rd }}$ ed. (Edinburgh: Edinburgh University Press, 2014).
} 
difference obliges, that difference (if it had anything) has the structure and nature of an obligation, prescription, and injunction, even if these terms can no longer be understood in accordance with its ethico-metaphysical concept. ${ }^{61}$

In this sense, the categorical imperative flows from our abandonment to difference, from the responsibility we have for meaning that cannot enjoy the security of a ground. The imperative commands sense whilst at the same time deferring it. ${ }^{62}$

The ethical dimension that Nancy identifies in differrance was later developed at length by Derrida with respect to deconstruction and the imperative of justice (their relationship defined infamously as one of direct equivalence: "Deconstruction is justice"63). Law, like any other textual field, is marked by its incapability to complete its economy of meaning. Différance is therefore irrepressibly inscribed in law, which as a result is always deconstructible. The obligation that law presents therefore, to create meaning and deliver sense, is the demand of justice. Against the strictures of a law of technical doctrine, justice requires invention and responsiveness. What Nancy allows us to understand is the inescapably social dimension of this movement, in the manner that finitude "presents itself as being-in-common". ${ }^{64}$ As an essential point of linkage, Simon Chesterman has argued that Derrida's formulation of justice should be understood as articulated in particular through English equity. He argues that the contradiction between common law and equity in the pursuit of justice is precisely the articulation of law's deconstruction at work. It is the excess, the other, the incapability of law to be fully present to itself. The mutual dependence of common law and equity, far from simply being an awkward remnant of legal history, allows for a justice to be maintained as aporia. ${ }^{5}$ This is not to say that equity 'is' the justice that the common law is incapable of delivering. Rather, justice is invented in the impossibility of its full presence, in the irreconcilability of the contradictions between their respective idioms. Equity therefore does not reach 'just' principles; justice is pursued in the obligation we have to take responsibility for law, animated by the antinomy of equity and common law. ${ }^{66}$

Whilst Chesterman himself is cynical about his conclusions supporting "the traditional conception of equity as a court of conscience", ${ }^{67}$ it is important to signpost the connections with the particular formulations of conscience laid out so far. To recap, Nancy redevelops the Heideggerian notion of conscience as an imperative of responsibility with respect to Being, in turn providing linkage with both the Kantian categorical imperative and the priority of Being-with. Freedom, thinking, writing-indeed,

\footnotetext{
${ }^{61}$ Nancy, 'Free Voice of Man', p. 46.

62 Ibid., p. 48.

${ }^{63}$ Jacques Derrida, 'Force of Law': The "Mystical Foundation of Authority" (1989) 11 Cardozo Law Review 920-1045, p. 945.

${ }^{64}$ Nancy, Inoperative Community, p. 28.

${ }^{65}$ Simon Chesterman, 'Beyond Fusion Fallacy: The Transformation of Equity and Derrida's “The Force of Law”" (1997) 24(3) Journal of Law and Society 350-376, p. 362.

66 Ibid.

${ }^{67}$ Ibid.
} 
Being itself - all take place in our abandonment to finitude, and laden with the obligation that this entails. In this sense, conscience is a form of responsibility for making and remaking law; not only a responsibility for what we make of the world, but also responsibility in the sense that invention is an unconditional necessity in the exposition of the 'with'. Equity may therefore be understood as a space of interruption, in which law's fixity can be undone and in which our unconditional responsibility for obligation can be assumed effectively. Such an account may go some way to explain the enduringly nebulous language of equitable obligation, that is, the rhetorical function of 'conscience' within legal discourse. Upon this view, equity produces interpersonal obligations precisely because it gives voice to the social affectivity of community. This is, therefore, a theory of equity as articulating primary obligation, of obligations that are not derivative of rights and entitlements, but which emerge in the unconditional underlying commitment to our social Being.

\section{Obligation and violence}

The argument developed the last section sets out a self-consciously optimistic reading of the significance of the social bond for our understanding of the imperative of conscience. Indeed, we have seen how Nancy helps us understand how an appeal to conscience can manifest as an intuitively acceptable mode of self-understanding. And how a commitment to obligation as such, one which expresses the ethical sensitivity of community, situates itself with respect to reason and law. Equity may well be an apposite site in which such a commitment finds expression in our familiar legal landscape. Nevertheless, a somewhat more guarded and perhaps cynical conclusion to the chapter as a whole will be put forward now. The idea of ontological obligation has ultimately led us to a kind of meta-imperative, irreducible to any concrete demand other than to keep asking and responding to the question of the demand as such. It delivers an obligation which necessarily dissolves in the moment in which it is grasped. As Gilbert-Walsh interprets this question of tangibility, "we are obliged, concretely, to maintain an open or undecided relation to our concrete end." ${ }^{8}$ As we have seen, obligation is therefore protected from reduction to some sort of static essence, and from the elevation of Dasein's destiny to an absolute priority, for instance. Nevertheless, to end this piece on a sceptical note, two main concerns can be put forward:

1. As already foreshadowed in the previous section, it may be claimed that the meaning of obligation is diluted by this structure. If conscience is an unconditional responsibility that is tied so tightly to Being, can we distance ourselves far enough from it to ask why it should be obeyed? Either one depicts obligation as something too abstract as to become meaningful in a normative sense (e.g. an obligation to keep open the question of obligation). Or we abandon the idea of a concrete imperative altogether, leaving us with a notion of singularities themselves constituted as living embodiments of their unconditional obligation, as Being-obligated, incapable of separating

\footnotetext{
${ }^{68}$ Gilbert-Walsh, 'Broken Imperatives', p. 41.
} 
themselves from their responsibility. After all, freedom cannot be detached from obligation at this ontological level. The most severe risk here is that we stray into the naturalistic fallacy: claiming an analysis that we are provides a reason as to why are obligated to be. Being-with is obligatory in a descriptive sense, but this alone cannot guarantee any meaningful normativity. Without a separation from freedom, obligation manifests as a categorical commitment to the general flux of Being. Without this gap, and without the critical distance it would provide, can one say that we are any more obligated by Being than the sea is obligated to bring in the tide?

2. The grounding of obligation in this manner, grounded precisely by the absence of grounding, risks the ideological consequences of granting obligation such a fundamental legitimacy. Such legitimacy is intensified by the claim that obligation has an effectively co-extensive relationship with freedom, and closes certain possibilities of thinking obligation as a form of violence. It is in a similar respect that Howard Caygill comments that "[t]he view of Mitsein or community being at war with itself over 'meaning' or the share of space and time" is rejected by Nancy, to the extent that his conception of freedom is incapable of addressing itself to historical political struggle. ${ }^{69}$

Point 1 relies on the idea that in order for an obligation to become properly comprehensible, it must emerge from the movement of Being to take on a tangible, comprehensible form. We have already considered how, for instance, synderesis would be inconsequential without the substantial and fallible work of conscientious application. In a sense, we have seen that Nancy agrees with this insofar as the alwaysinadequate ontical figuration of the imperative is necessary. But the point here extends further. There is a risk of thinking that the content of substantive law carries with it the unmediated normative weight of this ontological imperative, the weight of Being itself. At its most terrifying, we risk evoking a misty-eyed depiction of originary community as part of the everyday lived reality of positive law. Law may ultimately spring forth from the responsibilities of our ontological obligation, but that is very different from going so far as to say that ontology can pre-determine the norms we ultimately seek in discharging this responsibility. ${ }^{70}$

Point 2 introduces a further and related issue. That we find it hard to conceive obligation, or specifically conscience, without a sense of an externally voiced command, indicates the implicit violence in the way that such imperatives are experienced, felt, and articulated. It may be the case that one can argue for an ontological level of obligation, but as soon as obligation is animated in the delivery of language, and therefore as soon as it produces meaning that is comprehensible as law, we are necessarily drawn into the realm of force. Indeed, it is only by assuming its violent character that obligation can move us as a normative phenomenon. Violence in this sense is twofold. On the one hand, there exists the

\footnotetext{
${ }^{69}$ Howard Caygill, 'Philosophy, Violence, Freedom', in Simon Sparks (ed.) On Jean-Luc Nancy: The Sense of Philosophy (London: Routledge, 1997), pp. 19-31, at p. 26.

${ }^{70}$ Jean-Paul Martinon goes as far to say that "[Nancy's] imperative can never become law." Jean-Paul Martinon, 'Between Freedoms: Jean-Luc Nancy's Haunting Categorical Imperative' (2011) 10-11 Mono Kurgusuz Labirent 216226, p. 220.
} 
irruptive nature of obligation as an unconditional responsibility that disturbs the striation of established norms. But on the other hand, on the other side of aporia, is obligation as a graspable phenomenon, the command of law that always somehow fails to fully capture its ethical truth whilst simultaneously accusing the legal subject of her own ethical failings. By turning obligation and freedom into such close equivalents, we risk absenting this necessary violence from obligation, such that law (even abstracted as a 'law of the law') gains a naturalistic sense of incontrovertible legitimacy in which the force of its authority becomes shrouded. To extrapolate, if the thesis on equity, conscience and ontological obligation is accepted, then we also have to recognise the specific way in which this juridical language therefore naturalises obligation with inevitably ideological effects. Upon the analysis put forward in this chapter, equitable jurisprudence develops with an appeal to conscience, invoking the responsibility we take for judgment, and invoking the proximal sense of our own ethical Being. It presents the source of obligation as in us and cutting across us, as nothing less than the stark facticity of our freedom and our finitude. Yet, quoting Caygill again, this is a freedom that "can neither be recognized nor mourned". ${ }^{11}$ Freedom cannot question the ontological obligation it delivers. Likewise, expressing obligations in the language of conscience risks disabling us from recognising the violence of their legal force. One should continue to be wary, therefore, of a romanticised depiction of concrete equitable jurisprudence, mythogised as the unfettered voice of ethics and distanced from the necessary and often painful exigencies of grounded institutionalised judgment.

The theoretical resources analysed in this chapter help us to understand how law demands that we keep thinking and judging. It provides a possible explanation of the persistence of the idea of conscience, an idea that never completes itself while nevertheless continuing to animate a desire for justice in private law. But to arrive at a critical apparatus for interrogating obligation, one perhaps should be mindful of what Simon Critchley sees as the distinct risk of Nancy's thought: the exposition of Being as a with that has the effect of "flattening...the structure of ethical experience" by dissolving any sense of intersubjective radical separateness. ${ }^{72}$ Such critique counsels vigilance in understanding the necessity of violence in the obligatory nature of Being, the manner in which it impels a law of making a world in common. If Being obligates us, it nevertheless cannot tell us how to navigate the often dangerous and unforgiving terrain of the political. It is possible that conscience will not always speak the right answers.

\footnotetext{
${ }^{71}$ Caygill, 'Philosophy, Violence, Freedom', p. 25.

72 Simon Critchley, Ethics-Politics-Subjectivity: Essays on Derrida, Levinas and Contemporary French Thought (London: Verso, 2009), p. 251, original emphasis removed.
} 